\title{
DAMPAK INDUSTRIALISASI PEDESAAN TERHADAP KESEJAHTERAAN RUMAH TANGGA
}

\author{
The Impact of Rural Industrialization towards Household Welfare
}

\author{
Meliza Eka Adianty ${ }^{1)}$, Murdianto ${ }^{1)}$ \\ ${ }^{1)}$ Departemen Sains Komunikasi dan Pengembangan Masyarakat, Fakultas Ekologi Manusia, \\ Institut Pertanian Bogor, Darmaga Bogor 16680, Indonesia \\ E-mail: melizaekaadianty@gmail.com; murdianto@apps.ipb.ac.id
}

\begin{abstract}
Rural industrialization is one of the development step to increase economic growth. Indonesia has a huge opportunity in the development of industrialization. Nowadays, industrial activity has growth in rural areas. The entry of industry into rural area is expected to create employment and business opportunities for local community. Then it is expected to increase incomes and affect household welfare level. This study uses quantitative approach with survey method supported by qualitative data. The result of this research will show how the impact of rural industrialization which characterized by employment and business opportunity towards community welfare between them who have livelihood in industrial and non industrial sectors.
\end{abstract}

Keywords : job opportunities, business opportunities, industrial group, non industrial group

\begin{abstract}
ABSTRAK
Industrialiasasi pedesaan merupakan salah satu langkah pembangunan untuk mendorong pertumbuhan ekonomi. Indonesia memiliki peluang besar dalam perkembangan industrialisasi. Kegiatan industri pada masa kini telah merambah wilayah pedesaan. Masuknya industri ke pedesaan diharapkan mampu menciptakan kesempatan bekerja dan kesempatan berusaha bagi warga sekitar. Hal tersebut kemudian diharapkan mampu meningkatkan pendapatan warga dan pada akhirnya berpengaruh terhadap kesejahteraan tingkat rumah tangga. Penelitian ini menggunakan pendekatan kuantitatif dengan metode survei di dukung dengan data kualitatif. Hasil penelitian ini akan menunjukan bagaimana dampak industrialisasi pedesaan yang dicirikan dengan peluang bekerja dan peluang berusaha terhadap kesejahteraan masyarakat antara kelompok industri dan non industri.
\end{abstract}

Kata Kunci : peluang bekerja, peluang berusaha, kelompok industri, kelompok non industri

\section{PENDAHULUAN}

Indonesia memiliki peluang besar dalam perkembangan industrialisasi. Besarnya peluang Indonesia didukung oleh lokasi geografis dan lingkungan strategis negara ini. Dengan lokasi geografis yang menguntungkan dan keunggulan sebagai negara kepulauan yang memiliki akses ke laut yang pendek maka produk nasional dapat dipasarkan kemana saja. Lingkungan strategis Indonesia memiliki peluang besar untuk dibidik sebagai pasar ekspor, mitra berinvestasi, sumber teknologi, maupun sebagai tantangan dan pesaing. Selain itu, peluang melaksanakan industrialisasi di Indonesia juga sangat luas bila mengingat besarnya penduduk yang dimiliki. Potensi penduduk
Indonesia dapat dilihat dari dua perspektif. Pertama, jumlah penduduk Indonesia diatas 200 juta jiwa merupakan potensi sumber tenaga terampil dan wiraswasta. Kedua, jumlah penduduk besar adalah potensi pasar tersendiri. Dengan adanya pertumbuhan ekonomi serta dengan pendapatan per kapita maka jumlah penduduk tersebut merupakan pasar yang besar dan akan terus meningkat pertumbuhannya (Sastrosoenarto 2006).

Industri di Indonesia telah diatur dalam UndangUndang No.3 Tahun 2014 tentang Perindustrian. Menurut undang-undang tersebut, perindustrian adalah tatanan dan segala kegiatan yang bertalian dengan kegiatan industri. Industri merupakan seluruh bentuk kegiatan ekonomi yang mengolah 
bahan baku dan/atau memanfaatkan sumber daya industri sehingga menghasilkan barang yang mempunyai nilai tambah atau manfaat lebih tinggi, termasuk jasa industri. Bahan baku adalah bahan mentah, bahan setengah jadi, atau barang jadi yang dapat diolah menjadi barang setengah jadi atau barang yang mempunyai ekonomi yang lebih tinggi.

Menurut Yustika (2000) yang dikutip oleh Darojah (2012), industrialisasi di Indonesia pada akhirnya dapat menggeser aktivitas ekonomi masyarakat, yang semula bertumpu kepada sektor pertanian untuk kemudian bersandar kepada sektor industri. Kebijakan pemerintah yang terus mendorong pengembangan sektor industri (termasuk industri mikro-kecil dan menengah) ini menyebabkan kesempatan kerja di sektor industri kecil semakin lama juga semakin terbuka. Industrialisasi yang dijalankan harus bertumpu dan berkaitan dengan sektor pertanian, sehingga jika sektor industri sudah tumbuh pesat tidak lantas mematikan sektor pertanian yang menjadi tumpuan hidup masyarakatnya. Perubahan sistem ekonomi yaitu dari ekonomi pertanian ke ekonomi industri tentunya akan berpengaruh pula terhadap kehidupan sosial ekonomi masyarakat.

Indonesia merupakan negara yang kaya akan potensi sumber daya alam maupun sumber daya manusia. Sumber daya manusia yang dalam hal ini penduduk suatu negara, memegang peran penting dalam pembangunan untuk memanfaatkan sumber daya alam dan lingkungan demi kesejahteraan bersama secara berkelanjutan (BPS 2016). Penyerapan tenaga kerja oleh industri di sekitar pedesaan memberikan peluang bagi masyarakat sekitar untuk meningkatkan taraf hidupnya. Selain itu, dengan adanya industri di pedesaan juga memberi peluang bagi masyarakat untuk berusaha memenuhi kebutuhan hidup para tenaga kerja industri tersebut. Hal tersebut, secara tidak langsung akan meningkatkan kesejahteraan dengan memberikan upah terhadap pekerjanya yang bekerja pada industri tersebut maupun mereka yang membuka usaha karena adanya industri. Oleh karena itu, menarik untuk diteliti bagaimana dampak industrialisasi pedesaan terhadap kesejahteraan rumah tangga?

Industri di pedesaan pada sektor non-pertanian bertujuan untuk mengatasi masalah sosial ekonomi seperti masalah pengangguran. Keberadaan industri ini telah menciptakan lapangan kerja baru yang berbasis tenaga kerja lokal (Purwanto 2003). Selain itu, keberadaan industri nampaknya memberikan peluang baru bagi masyarakat sekitar untuk mendirikan usaha baru (Istiqomah dan Prasetyani 2013). Untuk itu menjadi menarik untuk diteliti mengenai bagaimana hubungan pendirian industri dengan peluang bekerja dan peluang berusaha?

Dampak keberadaan industri khususnya dalam hal kesempatan bekerja dan kesempatan berusaha diharapkan dapat berhubungan dengan kesejahteraan masyarakat sekitar industri di Desa Pasir Muncang. Semakin tinggi dampak keberadaan industri yang dirasakan masyarakat diharapkan dapat berakibat pada semakin tingginya tingkat kesejahteraan masyarakat. Namun dikhawatirkan, industri besar di pedesaan hanya sedikit menyerap tenaga kerja dan upah yang didapat relatif kecil karena latar belakang pendidikan yang umumnya masih rendah di daerah pedesaan. Oleh karena itu, menjadi menarik untuk diteliti bagaimana hubungan dampak industri dengan kesejahteraan rumah tangga?

\section{PENDEKATAN TEORITIS}

\section{Industrialisasi}

Menurut Undang-Undang No.3 Tahun 2014 tentang Perindustrian, perindustrian adalah tatanan dan segala kegiatan yang bertalian dengan kegiatan industri. Industri merupakan seluruh bentuk kegiatan ekonomi yang mengolah bahan baku dan/atau memanfaatkan sumber daya industri sehingga menghasilkan barang yang mempunyai nilai tambah atau manfaat lebih tinggi, termasuk jasa industri. Bahan baku adalah bahan mentah, bahan setengah jadi, atau barang jadi yang dapat diolah menjadi barang setengah jadi atau barang yang mempunyai ekonomi yang lebih tinggi.

Industrialisasi pada masa kini tidak hanya terjadi di perkotaan, namun telah merambah ke pedesaan. Tambunan (1989) dalam seminarnya menyampaikan bahwa industrialisasi pedesaan di Indonesia cenderung diartikan sebagai bagian dari pembangunan pedesaan (dengan ukuran industri kecil dan rumah tangga) dan bukan bagian pembangunan industri yang berfungsi meningkatkan produktivitas ekonomi. Fungsi industrialisasi yang lebih luas dari hanya sekedar untuk pemerataan pendapatan dan perluasan kesempatan kerja, antara lain paling strategis disebutkan sebagai berikut: 1) mendorong pertumbuhan pedesaan dengan mendiversifikasi sumber pendapatan, 2) meningatkan dampak pertumbuhan permintaan di dalam atau di luar suatu daerah, 3) meningkatkan 
kesempatan kerja baru, 4) mendekatkan hubungan fungsional, 5) meningkatkan produktivitas tenaga kerja dan industri, dan 6) mengurangi kemiskinan di pedesaan.

Sulasmono (1994) dalam penelitiannya mengungkapkan bahwa pembangunan industri meliputi tujuk aspek pokok yaitu 1) perijinan aras desa, 2) penentuan lokasi pabrik, 3) pembebasan tanah, 4) peluang kerja di pabrik, 5) peluang usaha, 6) migrasi, dan 7) polusi. Karakteristik industrialisasi pedesaan adalah padat karya, berbeda dengan industrialisasi perkotaan yang padat modal. Industrialisasi pedesaan menerapkan teknologi untuk meningkatkan produksi sesuai perkembangan masyarakat dan lingkungan pasar. Industrialisasi pedesaan sangat terkait dengan usaha skala kecil dan menengah sebagai pemain terbesar.

\section{Dampak Industrialisasi Pedesaan}

Menurut studi penelitian yang dilakukan Istiqomah dan Prasetyani (2013), aktivitas perekonomian yang terjadi sebagai dampak keberadaan kawasan industri di desa membawa beberapa perubahan terhadap masyarakat. Penduduk mampu memiliki peluang berwirausaha. Dahulu masyarakat hanya sebagai peternak saja. Kota Boyolali dikenal sebagai sentra penghasil susu. Namun terdapat permasalahan karena ketidakstabilan harga pakan ternak yang fluktuatif. Sedangkan bagi yang hanya berladang saja, kondisi tanah yang tandus maka hasil yang diperoleh tidak bisa dijadikan pemasukan utama. Lahan biasanya ditanami pepaya maupun singkong dan memiliki masa panen relatif lama, yakni 9-10 bulan. Ketika mulai didirikan industri, masyarakat mencoba peruntungan lain dengan menjadi wirausahawan dan ternyata dapat menambah penghasilan maupun menjadi penghasilan utama.

Purwanto (2003) dalam studi penelitiannya mengungkapkan bahwa industrialisasi menyebabkan perubahan kondisi lingkungan fisik dan non fisik yang pada akhirnya berdampak pada terbukanya peluang kesempatan kerja, kesempatan berusaha dan peluang terjadinya migrasi di daerah pedesaan. Lahan pertanian yang semakin sempit akibat alih fungsi lahan untuk pembangunan industri dan sarana penunjangnya dipaksa untuk menampung jumlah penduduk yang terus meningkat sehingga mengakibatkan menurunnya kegiatan ekonomi masyarakat berbasis pertanian. Namun pada sisi lain, masuknya industri membuka peluang bagi peningkatan ekonomi masyarakat. Masyarakat di sekitar lokasi pabrik dapat memanfaatkan peluang pekerjaan yang ditawarkan oleh pabrik. Para pemilik modal juga dapat memanfaatkan peluang berusaha yang terbuka akibat masuknya para pekerja migran dengan menyediakan jasa tempat pemondokan, transportasi ojek atau mendirikan toko dan warung. Bergesernya lahan untuk pembangunan kawasan industri mengakibatkan sejumlah petani lahan sempit beralih dari bidang pertanian ke bidang lain di luar pertanian. Pabrik-pabrik yang mulai beroperasi memberikan peluang-peluang bekerja yang lebih luas kepada masyarakat.

\section{Kesejahteraan}

Menurut Undang-Undang No.11 Tahun 2009 tentang Kesejahteraan Sosial, kesejahteraan sosial merupakan kondisi terpenuhinya kebutuhan material, spiritual, dan sosial warga negara agar dapat hidup layak dan mampu mengembangkan diri, sehingga dapat melaksanakan fungsi sosialnya.

Menurut Badan Pusat Statistik (2015) untuk melihat tingkat kesejahteraan rumah tangga suatu wilayah dapat menggunakan beberapa indikator yang dijadikan ukuran, antara lain: 1) akses terhadap kesehatan; 2) akses terhadap pendidikan; 3) tingkat pendapatan keluarga; 4) kondisi perumahan serta fasilitas yang dimiliki dalam rumah tangga; dan 5) taraf dan pola konsumsi dengan membandingkan pengeluaran untuk pangan dan non-pangan. Berikut adalah penjelasan lebih rinci mengenai indikator kesejahteraan yang dikeluarkan oleh Badan Pusat Statistik (BPS) pada tahun 2015.

\section{Dampak Industrialisasi Pedesaan terhadap Kesejahteraan Masyarakat}

Industrialisasi dianggap berpengaruh pada kenaikan produksi total sektor industri. Pada tahap selanjutnya industrialisasi akan mempengaruhi penggunaan faktor produksi, dan lebih lanjut penggunaan faktor produksi ini akan mempengaruhi penerimaan institusi (rumah tangga). Kenaikan penerimaan rumah tangga pedesaan inilah yang mencerminkan kenaikan kesejahteraan masyarakat di pedesaan (Prihawantoro S dan Muchdie 2000).

Hadirnya sektor industri di pedesaan pada berbagai kasus telah berdampak terhadap kesejahteraan rumah tangga masyarakat sekitar. Gandi (2011) berdasarkan hasil penelitiannya menyatakan bahwa berdirinya industri di pedesaan berdampak pada terbukanya kesempatan kerja non pertanian serta meningkatnya migrasi masuk. Untuk responden non industri, sebelum industri juga kebanyakan tidak bekerja dan setelah industri kebanyakan bekerja di 
bidang transportasi, pergudangan dan komunikasi. Setelah masuknya industri, tingkat pendapatan pada kelompok pertanian dan kelompok non pertanian meningkat. Hal ini telah menggambarkan salah satu variabel kesejahteraan.

\section{Kerangka Pemikiran}

Perkembangan industri di Indonesia yang kian pesat kini semakin merambah ke pedesaan. Seperti yang diungkapkan oleh Tambunan (1989) dalam seminarnya menyampaikan bahwa industrialisasi pedesaan di Indonesia cenderung diartikan sebagai bagian dari pembangunan pedesaan. Keberadaan industri di pedesaan menciptakan kesempatan bekerja dan juga peluang usaha bagi penduduk sekitar. Peluang kesempatan kerja baru juga merupakan salah satu fungsi industrialisasi menurut Tambunan (1989). Selain itu, peluang kerja di pabrik dan peluang usaha juga merupakan dua diantara tujuh aspek pokok pembangunan industri menurut penelitian Sulasmono (1994).

Purwanto (2003) dalam studi penelitiannya mengungkapkan bahwa industrialisasi menyebabkan perubahan kondisi lingkungan fisik dan non fisik yang pada akhirnya berdampak pada terbukanya peluang kesempatan kerja, kesempatan berusaha dan peluang terjadinya migrasi di daerah pedesaan. Menurunnya luas lahan-lahan pertanian dan meningkatnya tenaga kerja akibat peningkatan penduduk mengakibatkan kesempatan kerja di bidang pertanian menurun. Pabrik-pabrik yang mulai beroperasi memberikan peluang-peluang bekerja yang lebih luas kepada masyarakat.

Penelitian yang dilakukan Istiqomah dan Prasetyani (2013) bahwa aktivitas perekonomian yang terjadi sebagai dampak keberadaan lawasan industri di desa membawa beberapa perubahan terhadap masyarakat yakni penduduk mampu memiliki peluang berwirausaha. Selanjutnya menurut Prihawantoro S dan Muchdie (2000) industrialisasi akan mempengaruhi penggunaan faktor produksi, dan lebih lanjut penggunaan faktor produksi ini akan mempengaruhi penerimaan institusi (rumah tangga). Kenaikan penerimaan rumah tangga pedesaan inilah yang mencerminkan kenaikan kesejahteraan masyarakat di pedesaan.

Menurut Badan Pusat Statistik (2015) untuk melihat tingkat kesejahteraan rumah tangga suatu wilayah dapat menggunakan beberapa indikator yang dijadikan ukuran, antara lain: 1) akses terhadap kesehatan; 2) akses terhadap pendidikan; 3) tingkat pendapatan keluarga; 4) kondisi perumahan serta fasilitas yang dimiliki dalam rumah tangga; dan 5) taraf dan pola konsumsi dengan membandingkan pengeluaran untuk pangan dan non-pangan. Hasil penelitian Herlina, Oktavia, dan Elvawati (2014) menunjukkan dengan adanya industri di pedesaan, kesejahteraan masyarakat pedesaan cenderung meningkat. Oleh karena itu, penulis menggunakan keempat indikator tersebut untuk meneliti kesejahteraan rumah tangga.

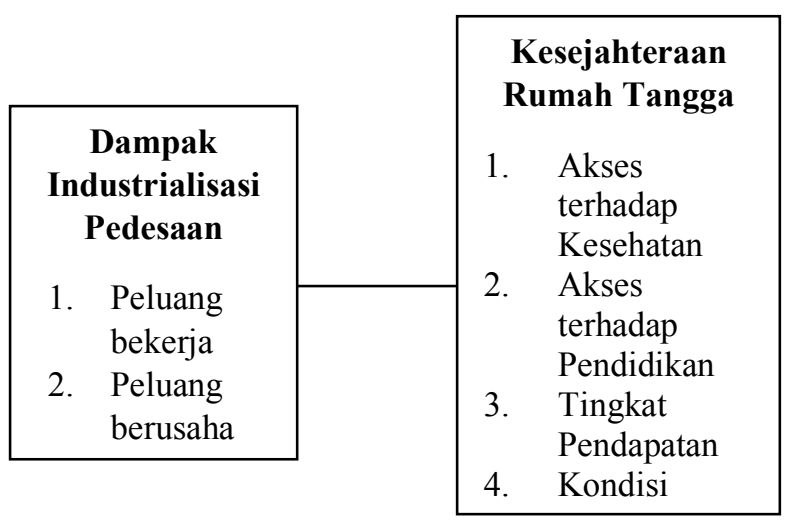

Keterangan:

$$
\begin{aligned}
& \text { : menjelaskan hubungan } \\
& : \text { data kuantitatif didukung dengan } \\
& \text { penjelasan kualitatif }
\end{aligned}
$$

Gambar 1 Kerangka pemikiran dampak industrialisasi pedesaan terhadap kesejahteraan rumah tangga

\section{METODE PENELITIAN}

Penelitian ini menggunakan metode kuantitatif yang didukung dengan data kualitatif. Metode kuantitatif dilakukan dengan menggunakan instrumen kuesioner dalam mengumpulkan data. Pengambilan data secara kualitatif dilakukan melalui wawancara mendalam, observasi dan studi dokumentasi terkait. Hasil wawancara mendalam digunakan sebagai masukan untuk menyempurnakan pertanyaan dalam kuesioner. Penelitian yang dilakukan termasuk ke dalam penelitian deskriptif dan penelitian penjelasan (explanatory research). Menurut Singarimbun dan Effendi (1989) penelitian deskriptif dilakukan untuk mengukur fenomena sosial tertentu, pengembangan konsep dan menghimpun fakta namun tidak melakukan pengujian hipotesa sedangkan penelitian penjelasan (explanatory research) dilakukan untuk menjelaskan hubungan antara variabel-variabel melalui pengujian hipotesa. Penelitian deskriptif 
digunakan untuk memperoleh informasi yang lebih mendalam mengenai kondisi sosial atau fakta suatu peristiwa di daerah tertentu.

Penelitian dilaksanakan pada masyarakat Desa Pasir Muncang, Kecamatan Caringin, Kabupaten Bogor. Pemilihan lokasi dilakukan secara purposive karena industri yang berada di sekitar pedesaan diduga dapat memberikan dampak secara langsung maupun tidak langsung terhadap masyarakat sekitar. Selain itu, jumlah pabrik di Desa Pasir Muncang juga menjadi pertimbangan bagi peneliti. Terdapat lima pabrik di Desa Pasir Muncang. Jumlah pabrik di Desa Pasir Muncang merupakan terbanyak kedua di Kecamatan Caringin. Lokasi penelitian difokuskan pada RW 01 dan RW 02 karena lokasi pabrik berdekatan dengan kedua RW ini.

Penelitian ini mempunyai dua jenis data yang akan diolah dan dianalisis, yaitu data kuantitatif dan data kualitatif. Data kuantitatif diolah menggunakan aplikasi Microsoft Excel 2007 dan SPSS version 21for windows. Data akan dianalisis dengan menggunakan tabel frekuensi, tabulasi silang, grafik atau diagram untuk melihat data awal responden pada masing-masing variabel secara tunggal menggunakan aplikasi Microsoft Excel 2007. Kemudian SPSS version 21 for Windows digunakan untuk uji statitistik yang akan menggunakan Rank Spearman Correlation.

Pembuatan tabel frekuensi dan diagram untuk melihat data awal responden untuk masing-masing variabel dan indikator secara tunggal menggunakan aplikasi Microsoft Excel 2007. Kemudian tabulasi silang digunakan untuk melihat kecenderungan dua variabel yang akan diuji yaitu dampak industrialisasi terhadap tingkat kesejahteraan rumah tangga dan karakteristik rumah tangga terhadap tingkat kesejahteraan rumah tangga. Kemudian digunakan SPSS version 21for windows untuk uji statistik. Pengujian akan dilakukan dengan menggunakan Rank Spearman Correlation untuk menganalisis ada atau tidaknya hubungan antara dua variabel yang berskala ordinal.

\section{HASIL DAN PEMBAHASAN}

\section{Hubungan Peluang Bekerja dan Akses Kesehatan}

Peluang bekerja merupakan variabel yang dikaitkan dengan responden industri. Peluang bekerja diukur dengan melihat kemampuan industri menciptakan lapangan pekerjaan baru. Selain itu, peluang bekerja juga diukur dengan melihat adakah kesempatan kerja bagi anggota keluarga dan seberapa banyak jumlah anggota keluarga yang bekerja pada industri di sekitar lokasi penelitian. Hal lain yang diukur dalam variabel ini adalah manfaat kehadiran industri yang dirasakan oleh responden, serta keterlibatan masyarakat yang bekerja pada industri tersebut. Sementara akses kesehatan diukur dengan melihat kemudahan responden dalam menjangkau fasilitas kesehatan yang diukur dengan waktu tempuh dalam satuan menit. Hal lain yang diukur adalah tenaga kesehatan yang dipilih responden pada saat berobat, apakah mantri, dokter praktek atau rumah sakit. Selain itu, indikator lainnya yang digunakan adalah sumber biaya yang digunakan untuk berobat serta penyelenggara fasilitas kesehatan.

Salah satu tujuan penelitian ini adalah untuk menjawab hipotesis uji. Pada sub-bab ini menguji satu hipotesis, yaitu diduga terdapat hubungan antara peluang kerja dengan akses kesehatan. Uji korelasi antara dua variabel dilakukan melalui tabulasi silang dan diuji menggunakan uji korelasi rank spearman untuk mengetahui seberapa kuat hubungan antara dua variabel.

Tabel 1 Jumlah dan persentase responden menurut tingkat peluang bekerja dan akses kesehatan di Desa Pasir Muncang tahun 2017

\begin{tabular}{lrrrrrr}
\hline \multirow{2}{*}{$\begin{array}{l}\text { Peluang } \\
\text { bekerja }\end{array}$} & \multicolumn{3}{c}{ Akses kesehatan } & \multicolumn{2}{c}{ Total } \\
\cline { 2 - 5 } & \multicolumn{3}{c}{ Tetap } & \multicolumn{3}{c}{ Meningkat } \\
& $\mathrm{n}$ & $\%$ & $\mathrm{n}$ & $\%$ & $\mathrm{n}$ & $\%$ \\
\hline Rendah & 0 & 0,0 & 0 & 0,0 & 0 & 0,0 \\
Sedang & 11 & 73,3 & 4 & 26,7 & 15 & 100,0 \\
Tinggi & 7 & 46,7 & 8 & 53,3 & 15 & 100,0 \\
\hline
\end{tabular}

Keterangan: koefisien korelasi industri $=0.272$. Nilai signifikansi $=0.146$

Hasil penelitian menunjukkan bahwa 73,3 persen responden dengan tingkat peluang bekerja sedang menyatakan tidak terdapat perubahan akses kesehatan saat sebelum maupun setelah hadirnya industri. Hal tersebut juga terjadi pada responden dengan peluang bekerja tinggi. Sebesar 7 orang responden mengatakan bahwa tidak terdapat perubahan dalam akses kesehatan setelah hadirnya industri. Sedangkan hanya sebesar 26,7 persen responden dengan peluang kerja sedang dan 53,3 persen responden dengan peluang kerja tinggi menyatakan bahwa terdapat peningkatan dalam akses kesehatan. Hal tersebut dikarenakan sebagian responden memilih untuk tetap berobat kepada 
dokter praktek karena alasan jarak dan lokasi yang lebih dekat dibandingkan rumah sakit rujukan dari jaminan kesehatan yang diajukan perusahaan.

\begin{abstract}
"Meskipun ada jaminan kesehatan dari perusahaan, saya lebih sering berobat ke dokter yang biasa. Kalau ke rumah sakit jauh dan mengeluarkan lebih banyak ongkos." (ITA, 40 tahun)

"Saya juga dari dulu sebelum kerja di pabrik udah berobat kesitu neng. Jadi kalau urusan jarak mah sama aja. Cuma bedanya sekarang jadi pake BPJS ini yang udah langsung dipotong gaji dari perusahaan." (SLH, 36 tahun)
\end{abstract}

Berdasarkan uji korelasi menggunakan rank spearman diperoleh nilai koefisien korelasi sebesar 0.272 dan nilai signifikasi 0.146 . Menurut Sarwono (2009) jika nilai koefisien korelasi berada diantara $0.25-0.5$ maka terdapat hubungan yang cukup kuat antara dua variabel. Sedangkan jika nilai signifikasi lebih besar dari taraf $\alpha(0.1)$ yaitu $0.146>0.1$ maka dapat disimpulkan bahwa tidak terdapat korelasi yang signifikan antara peluang bekerja dan akses kesehatan pada kelompok responden industri. Tidak adanya hubungan antara peluang bekerja dengan akses kesehatan pada responden industri dapat diartikan bahwa hadirnya industri dan peluang bekerja di pabrik tidak membawa dampak yang signifikan bagi responden meskipun memang terdapat jaminan kesehatan yang disediakan perusahaan melalui BPJS. Hal ini juga dapat dikarenakan responden telah memiliki akses kesehatan yang cukup baik pada saat sebelum hadirnya industri.

\section{Hubungan Peluang Berusaha dan Akses Kesehatan}

Bagian ini akan menjelaskan hubungan peluang berusaha dengan akses kesehatan sebagai salah satu indikator kesejahteraan masyarakat. Peluang berusaha merupakan variabel yang dikaitkan dengan responden dengan non industri. Peluang berusaha diukur dengan melihat kemampuan keberadaan industri menciptakan kesempatan membuka usaha baru. Selain itu, peluang berusaha juga diukur dengan melihat adakah kesempatan bagi responden mendirikan usaha dan seberapa banyak jumlah anggota keluarga yang terlibat dalam usaha. Hal lain yang diukur dalam variabel ini adalah manfaat kehadiran industri yang dirasakan oleh responden, serta peran pekerjaan dalam mencukupi kebutuhan hidup sebelum dan setelah adanya industri.
Hubungan antara dua variabel tersebut dijelaskan dalam Tabel 2 berikut.

Tabel 2 Jumlah dan persentase responden menurut tingkat peluang berusaha dan akses kesehatan di Desa Pasir Muncang tahun 2017

\begin{tabular}{|c|c|c|c|c|c|c|}
\hline \multirow{3}{*}{$\begin{array}{l}\text { Peluang } \\
\text { berusaha }\end{array}$} & \multicolumn{4}{|c|}{ Akses kesehatan } & \multicolumn{2}{|c|}{ Total } \\
\hline & \multicolumn{2}{|c|}{ Tetap } & \multicolumn{2}{|c|}{ Meningkat } & & \\
\hline & $\sum$ & $\%$ & $\sum$ & $\%$ & $\sum$ & $\%$ \\
\hline Rendah & 5 & 62,5 & 3 & 37,5 & 8 & 100,0 \\
\hline Sedang & 8 & 57,1 & 6 & 42,9 & 14 & 100,0 \\
\hline Tinggi & 6 & 75,0 & 2 & 25 & 8 & 100,0 \\
\hline
\end{tabular}

Keterangan: koefisien korelasi non-industri $=0.186$. Nilai signifikansi $=0.324$

Data yang diperoleh dari tabel di atas menunjukkan bahwa sebesar 25 persen responden mengalami peluang berusaha tinggi. Hal ini berimplikasi pada peningkatan akses terhadap kesehatan yang ditandai dengan beralihnya fasilitas kesehatan yang dipilih dari mantri ke dokter praktek maupun rumah sakit. Selain itu, 42,9 persen responden dengan peluang berusaha sedang juga mengalami peningkatan demikian. Meningkatnya akses kesehatan juga terjadi pada 37,5 persen responden dengan peluang usaha rendah. Namun tingginya peluang berusaha tidak selalu berimplikasi pada peningkatan akses terhadap kesehatan. Sebesar 6 responden dengan peluang berusaha tinggi menyatakan bahwa hadirnya peluang berusaha tidak membuat akses kesehatan meningkat. Selain itu, sebesar 57,1 persen responden dengan peluang berusaha sedang juga tidak mengalami perubahan peningkatan akses kesehatan. Kondisi ini dapat disebabkan karena responden telah memiliki usaha yang baik sehingga telah mampu menjangkau akses kesehatan yang baik. Sedangkan sebesar 8 orang responden dengan peluang berusaha rendah tidak mengalami perubahan akses kesehatan dapat dikarenakan mereka memang memiliki peluang usaha yang rendah baik sebelum maupun setelah industri sehingga tetap memilih mantri atau tetap memilih dokter sebagai fasilitas kesehatan yang dipilih.

\footnotetext{
"Kalau ke rumah sakit cukup jauh. Lebih baik ke Dokter Eko yang lebih dekat hanya 10 menit, bisa jalan kaki. Kalau adanya pabrik tidak berubah sih fasilitas kesehatan disini." (MAS, 45 tahun)
}

Berdasarkan uji korelasi menggunakan rank spearman diperoleh nilai koefisien korelasi sebesar 
0.186 dan nilai signifikansi sebesar 0.324 . Menurut Sarwono (2009) jika nilai koefisien korelasi bernilai $>0-0.25$ maka terdapat korelasi yang sangat lemah antar variabel. Sedangkan jika nilai signifikansi bernilai 1.000 atau lebih besar dari taraf $\alpha(0.10)$ yaitu $0.324>0.10$ maka dapat disimpulkan bahwa tidak terdapat hubungan antara peluang berusaha dan akses kesehatan pada kelompok responden non industri. Tidak adanya hubungan ini dapat disebabkan karena hadirnya pabrik di Desa Pasir Muncang tidak memberi dampak signifikan bagi akses kesehatan masyarakat. Hal ini dapat disebabkan karena memang tidak adanya bantuan penyelenggaraan pelayanan kesehatan umum yang diberikan untuk masayrakat sekitar.

\section{Hubungan Peluang Bekerja dan Akses Pendidikan}

Tujuan lainnya dari penelitian ini adalah untuk membuktikan hipotesis mengenai hubungan peluang bekerja dengan akses pendidikan pada responden industri. Akses pendidikan dalam penelitian ini dilihat dari sampai pada tingkat apa responden maupun anggota keluarga mampu menyelesaikan pendidikan baik pada saat sebelum maupun setelah hadirnya industri. Penelitian bertujuan untuk mengetahui apakah terjadi perubahan kondisi atau tidak. Tingkat pendidikan dalam penelitian ini adalah Sekolah Dasar (SD) atau sederajat, Sekolah Menengah Pertama (SMP) atau sederajat, Sekolah Menengah Atas (SMA) atau sederajat dan Perguruan Tinggi. Selain itu, indikator lainnya yang diukur adalah kemudahan responden maupun anggota keluarga dalam menjangkau fasilitas pendidikan serta sumber biaya yang digunakan pendidikan.

Tabel 3 Jumlah dan persentase responden menurut tingkat peluang bekerja dan akses pendidikan di Desa Pasir Muncang tahun 2017

\begin{tabular}{|c|c|c|c|c|c|c|}
\hline \multirow{3}{*}{$\begin{array}{l}\text { Peluang } \\
\text { bekerja }\end{array}$} & \multicolumn{4}{|c|}{ Akses pendidikan } & \multicolumn{2}{|c|}{ Total } \\
\hline & \multicolumn{2}{|c|}{ Tetap } & \multicolumn{2}{|c|}{ Meningkat } & & \\
\hline & $\sum$ & $\%$ & $\sum$ & $\%$ & $\sum$ & $\%$ \\
\hline Rendah & 0 & 0,0 & 0 & 0,0 & 0 & 0,0 \\
\hline Sedang & 11 & 73,3 & 4 & 26,7 & 15 & 100,0 \\
\hline Tinggi & 9 & 60,0 & 6 & 40,0 & 15 & 100,0 \\
\hline
\end{tabular}

Keterangan: koefisien korelasi industri $=0.111$. Nilai signifikansi $=0.559$

Berdasarkan data yang tersaji pada tabel 3, terdapat 60 persen responden yang menyatakan bahwa hadirnya industri mampu memberikan peluang kerja tinggi di perusahaan. Sebagian besar perusahaan menetapkan persyaratan tertentu untuk merekrut tenaga kerja, salah satunya yaitu tingkat pendidikan akhir yang diselesaikan hingga SMA atau sederajat. Sehingga responden dengan mudahnya mendaftar kerja ke perusahaan karena telah memiliki ijazah SMA sebelum hadirnya industri. Selain itu, 73,3 persen responden dengan tingkat peluang bekerja sedang juga menyatakan bahwa hal tersebut tidak berimplikasi pada perubahan akses pendidikan mereka.

"Saya sudah lulus SMA sebelum adanya
pabrik. Saat ada pabrik jadi saya tidak kejar
paket C semacamnya. Rata-rata warga disini
juga sepertinya begitu." (IYS, 32 tahun)

Sementara hanya terdapat 26,7 persen responden dengan peluang bekerja sedang dan 40 persen responden peluang bekerja tinggi yang menyatakan bahwa hadirnya industri berdampak terhadap peningkatan peluang bekerja sekaligus meningkatkan akses terhadap pendidikan. Hal tersebut dilihat dari perubahan tingkat pendidikan yang mampu ditempuh oleh anggota keluarga responden.

“... dengan saya bekerja di pabrik seperti sekarang ini, insya Allah bisa menyekolahkan anak hingga SMA. Inginnya sampai kuliah. Lain halnya kalau saya nggak bekerja, mungkin belum tentu bisa menyekolahkan." (MEU, 40 tahun)

Berdasarkan uji korelasi menggunakan rank spearman diperoleh nilai koefisien korelasi sebesar 0.111 dan nilai signifikasi 0.559. Menurut Sarwono (2009) jika nilai koefisien korelasi bernilai $>0-0.25$ maka terdapat korelasi yang sangat lemah antar variabel. Sedangkan jika nilai signifikasi lebih besar dari taraf $\alpha(0.10)$ yaitu $0.559>0.10$ maka dapat disimpulkan tidak terdapat korelasi antara peluang bekerja dan akses pendidikan pada kelompok responden industri. Hal ini dikarenakan sebagian besar responden telah mencapai jenjang pendidikan yang tinggi (SMA dan sederajat) sebelum hadirnya industri.

\section{Hubungan Peluang Berusaha dan Akses Pendidikan}

Sub-bab ini akan memaparkan hasil penelitian mengenai hubungan peluang kerja atau usaha non pertanian dengan akses pendidikan sebagai salah 
satu indikator kesejahteraan masyarakat. Perbedaan perubahan akses responden non industri terhadap akses pendidikan ditunjukkan pada Tabel 4 .

Tabel 4 Jumlah dan persentase responden menurut tingkat peluang berusaha dan akses pendidikan di Desa Pasir Muncang tahun 2017

\begin{tabular}{lrrrrrrr}
\hline Peluang & \multicolumn{3}{c}{ Akses pendidikan } & \multicolumn{2}{l}{ Total } \\
\cline { 2 - 5 } berusaha & \multicolumn{2}{c}{ Tetap } & \multicolumn{3}{c}{ Meningkat } & & \\
\cline { 2 - 6 } & $\sum$ & $\%$ & $\sum$ & $\%$ & $\sum$ & $\%$ \\
\hline Rendah & 6 & 75,0 & 2 & 25,0 & 8 & 100,0 \\
\hline Sedang & 11 & 78,6 & 3 & 21,4 & 14 & 100,0 \\
\hline Tinggi & 5 & 62,5 & 3 & 37,5 & 8 & 100,0 \\
\hline
\end{tabular}

Keterangan: koefisien korelasi non-industri $=0.103$. Nilai signifikansi $=0.587$

Sebesar 62,5 persen responden non industri menyatakan kehadiran industri mampu membuat peluang usaha menjadi tinggi namun responden ini tidak mengalami perubahan tingkat pendidikan. Selain itu, sebanyak 11 orang responden dengan peluang berusaha sedang juga tidak mengalami perubahan tingkat pendidikan. Hal ini dikarenakan responden non industri telah mampu mengakses pendidikan hingga tingkat yang cukup tinggi yaitu SMA/sederajat bahkan perguruan tinggi sebelum hadirnya industri. Sementara itu, sebanyak 6 orang responden dengan peluang berusaha rendah juga menyatakan akses pendidikan tidak mengalami perubahan setelah hadirnya industri karena responden ini sudah merasa cukup dengan pendidikan yang dicapai dan tidak merasa membutuhkan untuk melanjutkan pendidikan ke jenjang yang lebih tinggi. Sedangkan sebesar 2 orang responden pada peluang berusaha rendah, 3 orang responden dengan peluang berusaha sedang dan 3 orang dengan peluang berusaha tinggi menyatakan terdapat perubahan peningkatan akses pendidikan.

\section{"Saya kalau pendidikan alhamdulillah sampai D4. Dulu memang pernah bekerja di Jakarta, namun lama-lama lelah juga setiap hari pulang pergi. Alhamdulillah anak saya tetap bisa lanjut kuliah dari pendapatan buka kelontong ini." (MUS, 45 tahun) \\ "Kalau buka warung makan gini mah menurut saya tidak perlu sekolah lagi. Jalanin saja yang ada." (MLN, 32 tahun)}

Berdasarkan uji korelasi menggunakan rank spearman diperoleh nilai koefisien korelasi sebesar 0.103 dan nilai signifikasi 0.587 . Menurut Sarwono
(2009) jika nilai koefisien korelasi berada diantara $>$ $0-0.25$ maka terdapat korelasi yang sangat lemah antar variabel. Sedangkan jika nilai signifikasi lebih besar dari taraf $\alpha(0.10)$ yaitu $0.587>0.10$ maka dapat disimpulkan bahwa tidak terdapat korelasi antara peluang berusaha dan akses pendidikan pada kelompok responden non industri.

\section{Hubungan Peluang Bekerja dan Pendapatan}

Tingkat pendapatan responden sebelum dan setelah industri diukur dengan melihat perubahan pendapataan yang riil terjadi pada masing-masing responden, apakah terjadi perubahan menurun, tetap atau perubahan meningkat. Lalu pada saat sebelum dan setelah hadirnya industri, pendapatan responden dihitung untuk mendapatkan standar deviasi dan rata-rata. Setelah itu dapat dilihat apakah responden memiliki perubahan pendapatan setelah terjadinya industri. Bagian ini akan menjelaskan hubungan peluang bekerja dengan tingkat pendapatan sebagai salah satu indikator kesejahteraan masyarakat. Hubungan antara dua variabel tersebut dijelaskan dalam Tabel 5.

Tabel 5 Jumlah dan persentase responden menurut tingkat peluang bekerja dan pendapatan di Desa Pasir Muncang tahun 2017

\begin{tabular}{lrrrrrr}
\hline Peluang & \multicolumn{3}{c}{ Pendapatan } & \multicolumn{2}{c}{ Total } \\
\cline { 2 - 5 } bekerja & \multicolumn{2}{c}{ Tetap } & \multicolumn{3}{c}{ Meningkat } & \\
\cline { 2 - 6 } & $\sum$ & $\%$ & $\sum$ & $\%$ & $\sum$ & $\%$ \\
\hline Rendah & 0 & 0,0 & 0 & 0,0 & 0 & 0,0 \\
\hline Sedang & 15 & 100,0 & 0 & 0,0 & 15 & 100,0 \\
\hline Tinggi & 12 & 80,0 & 3 & 20,0 & 15 & 100,0 \\
\hline
\end{tabular}

Keterangan: koefisien korelasi industri $=0.333$. Nilai signifikansi $=0.072$

Hasil penelitian menunjukkan bahwa terdapat 12 orang responden yang menyatakan peluang bekerja tinggi dan tidak ada perubahan pendapatan. Selain itu, 15 orang responden pada kelompok peluang bekerja kategori sedang juga menyatakan hal yang sama. Hal ini dikarenakan pada kelompok tersebut, sebelum hadirnya industri mereka sudah memiliki pekerjaan dengan pendapatan yang sama dengan saat ini.

\footnotetext{
"Sebelum adanya pabrik di sekitar sini dulu saya juga sudah lumayan pendapatannya. Sama sudah UMR dengan sekarang. Tapi sekarang mah pindah kerja disini karena lebih dekat, lebih efisien nggak perlu berangkat pagi-pagi dan tidak perlu banyak ongkos." (DDI, 30 tahun)
} 
Sementara itu, terdapat sebesar 20 persen responden yang menyatakan peluang bekerja tinggi setelah adanya industri dan pendapatannya meningkat. Hal ini dikarenakan pada kelompok tersebut, setelah hadirnya industri mereka tidak menganggur dan mampu memiliki pekerjaan di atas UMR dan di atas pendapatan rata-rata.

\section{"Waktu dulu mah 2008 saya masih sekolah. Tahun 2012 saya masuk kesitu (industri) dan sekarang alhamdulillah sudah punya penghasilan sendiri." (FRA, 23 tahun) \\ "Lulus SMA saya pernah kerja di pabrik garmen setahun, tapi di daerah Sukabumi UMR-nya lebih rendah daripada Bogor neng. Terus pindah kesini semenjak pabrik minuman itu buka. Alhamdulillah pendapatan naik dan lokasi deket sama rumah juga." (DHL, 27 tahun)}

Berdasarkan uji korelasi menggunakan rank spearman diperoleh nilai koefisien korelasi sebesar 0.333 dan nilai signifikasi 0.072 . Menurut Sarwono (2009) jika nilai koefisien korelasi berada diantara > 0.25-0.5 maka terdapat hubungan yang cukup kuat. Sedangkan jika nilai signifikasi lebih kecil dari taraf $\alpha(0.10)$ yaitu $0.072<0.10$ maka dapat disimpulkan bahwa terdapat korelasi yang signifikan antara peluang bekerja dan pendapatan pada kelompok responden industri.

\section{Hubungan Peluang Berusaha dan Pendapatan}

Pengujian hipotesis lainnya yang dilakukan dalam penelitian mengenai dampak industrialisasi pedesaan terhadap tingkat kesejahteraan masyarakat adalah dengan melihat hubungan antara peluang berusaha dengan pendapatan yang dialami oleh responden. Hubungan antara dua variabel tersebut dijelaskan dalam Tabel 6 .

Tabel 6 Jumlah dan persentase responden menurut tingkat peluang berusaha dan pendapatan di Desa Pasir Muncang tahun 2017

\begin{tabular}{|c|c|c|c|c|c|c|}
\hline \multirow{3}{*}{$\begin{array}{l}\text { Peluang } \\
\text { berusaha }\end{array}$} & \multicolumn{4}{|c|}{ Pendapatan } & \multicolumn{2}{|c|}{ Total } \\
\hline & \multicolumn{2}{|c|}{ Tetap } & \multicolumn{2}{|c|}{ Meningkat } & & \\
\hline & $\sum$ & $\%$ & $\sum$ & $\%$ & $\sum$ & $\%$ \\
\hline Rendah & 7 & 87,5 & 1 & 12,5 & 8 & 100,0 \\
\hline Sedang & 7 & 50,0 & 7 & 50,0 & 14 & 100,0 \\
\hline Tinggi & 6 & 75,0 & 2 & 25,0 & 8 & 100,0 \\
\hline
\end{tabular}

Keterangan: koefisien korelasi non industri $=0.097$. Nilai signifikansi $=0.611$

Berdasarkan data yang disajikan pada tabel 6 diketahui bahwa terdapat 25 persen responden menyatakan bahwa hadirnya industri membuat peluang berusaha tinggi dan pendapatan meningkat. Sementara 50 persen responden menyatakan peluang berusaha sedang setelah hadirnya industri dan pendapatan meningkat. Hal serupa juga dinyatakan oleh 22,5 persen responden yang menganggap bahwa setelah hadirnya industri pendapatan meningkat meskipun peluang berusaha rendah.

"Sebelum ada pabrik disini saya
menjadi ibu rumah tangga saja. Tapi
setelah adanya pabrik, buka warung
kecil-kecilan untuk menambah
penghasilan. Cukup untuk jajan
anak." (KUS, 45 tahun)

Sedangkan 75 persen responden dengan peluang berusaha tinggi, 50 persen responden peluang berusaha sedang dan 87,5 persen responden dengan peluang usaha rendah menyatakan tidak terdapat perubahan pendapatan setelah adanya industri. Hal ini dapat dikarenakan sebagian besar responden telah memiliki pekerjaan dengan pendapatan yang cukup menjamin kebutuhan hidup sebelum hadirnya industri. Selain itu, tidak terdapatnya perubahan juga dikarenakan responden telah membuka usaha sebelum hadirnya pabrik di sekitar pemukiman warga.

"Nggak terlalu besar efeknya neng. Sekarang
mah udah banyak warung. Kalau pas awal iya
kerasa meningkatnya. Sekarang mah
kayaknya segini-gini aja. Lagian juga pabrik
disini mah tidak besar, jadi sedikit
karyawannya yang beli." (MDK, 65 tahun)
"Kalau perubahan karena adanya industri
mah nggak ya, soalnya usaha ini memang
alhamdulillah sudah lancar sebelum adanya
industri disini juga." (HIL, 30 tahun)

Berdasarkan uji korelasi menggunakan rank spearman diperoleh nilai koefisien korelasi sebesar 0.097 dan nilai signifikasi 0.611. Menurut Sarwono (2009) jika nilai koefisien korelasi $>0-0.25$ maka terdapat korelasi yang sangat lemah. Sedangkan jika nilai signifikasi lebih besar dari taraf $\alpha(0.10)$ yaitu $0.611>0.10$ maka dapat disimpulkan bahwa tidak terdapat korelasi antara peluang berusaha dan pendapatan pada kelompok responden non industri. Tidak terdapatnya hubungan ini mengindikasikan bahwa kehadiran pabrik tidak memiliki dampak yang cukup besar untuk peluang berusaha bagi warga. Hal ini dapat dikarenakan jenis pabrik yang merupakan industri pengolahan minuman sehingga kurang memungkinkan warga untuk mengkreasikan usaha serupa maupun menjalin mitra usaha dengan pabrik. 


\section{Hubungan Peluang Bekerja dan Kondisi tempat tinggal serta fasilitas yang dimiliki}

Indikator lain yang digunakan untuk mengukur tingkat kesejahteraan masyarakat adalah dengan melihat kondisi tempat tinggal dan fasilitas yang dimiliki. Seperti yangtelah dipaparkan pada bab sebelumnya, kondisi tempat tinggalserta fasilitas yang dimiliki responden dinilai dari status kepemilikan rumah, jenis atap rumah, jenis dinding rumah, jenis lantai rumah, fasilitas tempat MCK, sumber penerangan, sumber air minum,serta kepemilikan harta. Sub-bab ini akan menjelaskan hasil penelitian mengenai hubungan peluang bekerja dengan kondisi tempat tinggal dan fasilitas yang dimiliki responden saat sebelum maupun setelah hadirnya industri di Desa Pasir Muncang, Kecamatan Caringin, Kabupaten Bogor.

Tabel 7 Jumlah dan persentase responden menurut tingkat peluang bekerja dan kondisi tempat tinggal serta fasilitas yang dimiliki di Desa Pasir Muncang tahun 2017

\begin{tabular}{|c|c|c|c|c|c|c|}
\hline \multirow{3}{*}{$\begin{array}{l}\text { Peluang } \\
\text { bekerja }\end{array}$} & \multicolumn{4}{|c|}{ Kondisi dan fasilitas } & \multicolumn{2}{|c|}{ Total } \\
\hline & \multicolumn{2}{|c|}{ Tetap } & \multicolumn{2}{|c|}{ Meningkat } & & \\
\hline & $\sum$ & $\%$ & 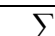 & $\%$ & $\overline{5}$ & $\%$ \\
\hline Rendah & 0 & 0,0 & 0 & 0,0 & 0 & 0,0 \\
\hline Sedang & 2 & 13,3 & 13 & 86,7 & 15 & 100,0 \\
\hline Tinggi & 1 & 6,7 & 14 & 93,3 & 15 & 100,0 \\
\hline
\end{tabular}

Keterangan: koefisien korelasi industri $=0.111$. Nilai signifikansi $=0.559$

Hasil penelitian menunjukkan sebanyak 14 orang responden yang berpeluang kerja tinggi mengalami peningkatan kondisi serta fasilitas tempat tinggal yang dimiliki. Sama halnya dengan 13 orang responden yang berpeluang kerja sedang juga mengalami peningkatan kondisi dan fasilitas tempat tinggal yang dimiliki.

"Setelah kerja di pabrik saya bisa
membeli motor, meskipun masih
mencicil." (SYD, 33 tahun)
"Alhamdulillah bisa membeli barang
elektronik kayak mesin cuci dulu mah
nggak punya. Saya juga bisa renovasi
rumah sedikit-sedikit." (JKS, 25 tahun)

Kehadiran industri tidak serta merta meningkatkan peluang bekerja dan kondisi tempat tinggal dan fasilitas rumah. Hal ini terlihat pada 13,3 persen responden dengan peluang bekerja sedang dan 6,7 persen peluang bekerja tinggi. Responden merasa tidak terdapat perubahan pada kondisi dan fasilitas rumah tinggalnya. Hal ini dapat dikarenakan responden telah memiliki tempat tinggal dan fasilitas yang layak sebelum hadirnya industri.

“... sebelum ada pabrik juga rumah saya
sudah seperti ini. Bisa membeli barang
elektronik tapi tidak banyak, karena
memang sudah ada. Kalau renovasi
rumah mah tidak.” (ADZ, 26 tahun)

Berdasarkan uji korelasi menggunakan rank spearman diperoleh nilai koefisien korelasi sebesar 0.111 dan nilai signifikasi 0.559 . Menurut Sarwono (2009) jika nilai koefisien korelasi $>0-0.25$ maka terdapat korelasi yang sangat lemah. Sedangkan jika nilai signifikasi lebih besar dari taraf $\alpha(0.10)$ yaitu $0.559>0.10$ maka dapat disimpulkan bahwa tidak terdapat korelasi antara peluang bekerja dan kondisi tempat tinggal serta fasilitas yang dimiliki pada kelompok responden industri.

\section{Hubungan Peluang Berusaha dan Kondisi tempat tinggal serta fasilitas yang dimiliki}

Pengujian hipotesis lainnya dalam penelitian ini adalah untuk mengetahui hubungan antara mengenai hubungan peluang bekerja dengan kondisi tempat tinggal dan fasilitas yang dimiliki oleh responden. Perubahan kondisi sebelum dan setelah hadirnya industri dilihat peluang berusaha serta perubahan dengan kondisi tempat tinggal dan fasilitas dijelaskan pada Tabel 8 .

Tabel 8 Jumlah dan persentase responden menurut tingkat peluang berusaha dan kondisi tempat tinggal serta fasilitas yang dimiliki di Desa Pasir Muncang tahun 2017

\begin{tabular}{lrrrrrrr}
\hline Peluang & \multicolumn{3}{l}{ Kondisi dan fasilitas } & \multicolumn{2}{l}{ Total } \\
\cline { 2 - 5 } berusaha & \multicolumn{2}{l}{ Tetap } & \multicolumn{3}{l}{ Meningkat } & & \\
\cline { 2 - 6 } & $\sum$ & $\%$ & $\sum$ & $\%$ & $\sum$ & $\%$ \\
\hline Rendah & 2 & 25,0 & 6 & 75,0 & 8 & 100,0 \\
\hline Sedang & 2 & 14,3 & 12 & 85,7 & 14 & 100,0 \\
\hline Tinggi & 3 & 37,5 & 5 & 62,5 & 8 & 100,0 \\
\hline
\end{tabular}

Keterangan: koefisien korelasi non industri $=-0.108$. Nilai signifikansi $=0.570$

Data yang disajikan pada Tabel 8 menunjukkan bahwa hanya 85,7 persen responden menyatakan peluang berusaha sedang setelah hadirnya industri. Hal ini juga berhubungan dengan meningkatnya 
kondisi serta fasilitas tempat tinggal responden. Sebesar 75 persen responden dengan peluang berusaha rendah dan 62,5 persen responden dengan peluang berusaha tinggi menyatakan peluang bekerja rendah juga menyatakan kondisi dan fasilitas rumah meningkat.

"Setelah adanya industri, saya awalnya tidak bekerja. Sekarang mampu membuka usaha warung ini. Kalau untuk beli barang berharga seperti emas belum menutupi. Tapi kalau beli perabotan sedikit-sedikit bisa." (YNT, 44 tahun)

Sedangkan 25 persen responden dengan peluang berusaha rendah, 14,3 persen dengan peluang berusaha sedang, dan 37,5 persen responden dengan peluang berusaha tinggi menyatakan tidak terdapat perubahan kondisi dan fasilitas rumah. Hal tersebut dikarenakan sebelum hadirnya industri, responden tersebut telah memiliki pekerjaan yang layak sehingga memiliki kondisi tempat tinggal serta kepemilikan fasilitas yang sesuai karakteristik kesejahteraan nasional.

\section{"Kalau dulu iya saya belum punya usaha seperti sekarang ini. Tapi kalau ditanya soal fasilitas rumah sih, sepertinya tidak ada perbedaan. Memang dari dulu seperti ini." (MAR, 65 tahun)}

Berdasarkan uji korelasi menggunakan rank spearman diperoleh nilai koefisien korelasi sebesar 0.108 dan nilai signifikasi 0.570 . Menurut Sarwono (2009) jika nilai koefisien korelasi $>0-0.25$ maka terdapat korelasi yang sangat lemah. Sedangkan jika nilai signifikasi lebih kecil dari taraf $\alpha(0.10)$ yaitu $0.570>0.10$ maka dapat disimpulkan bahwa tidak terdapat korelasi antara peluang berusaha dan kondisi tempat tinggal serta fasilitas yang dimiliki pada kelompok responden non industri.

\section{SIMPULAN DAN SARAN}

\section{Simpulan}

Hadirnya industri di pedesaan dapat meningkatkan pendapatan bagi responden industri. Hal ini terlihat dari adanya hubungan antara peluang bekerja dengan pendapatan. Bagi responden industri, hadirnya industri di pedesaan telah membuka peluang bekerja baru yakni sebagai karyawan pabrik. Namun bagi responden non industri, hadirnya industri dinilai telah membuka berbagai peluang berusaha. Namun terbukanya peluang berusaha tidak serta merta berhubungan dengan tingkat pendapatan yang diperoleh. Terdapat responden yang mulanya tidak memiliki pekerjaan dan tidak memiliki pendapatan, dengan hadirnya industri mampu memberikan peluang usaha sehingga memiliki pendapatan walaupun masih di bawah rata-rata pendapatan saat setelah hadirnya industri. Hubungan lainnya tidak ditunjukkan dalam akses kesehatan, akses pendidikan maupun kondisi dan fasilitas tempat tinggal. Hal ini dapat dikarenakan responden telah dapat mengakses hal tersebut sebelum hadirnya industri.

Hal tersebut juga ditunjukkan oleh responden non industri. Meningkatnya peluang usaha akibat kehadiran industri dinilai tidak berhubungan dengan keseluruhan variabel (akses kesehatan, akses pendidikan, pendapatan, serta kondisi dan fasilitas tempat tinggal).Hal ini dapat disebabkan responden kurang memperhatikan pentingnya pendidikan tinggi. Berdasarkan data desa, mayoritas penduduk Desa Pasir Muncang memang telah menempuh pendidikan tinggi hingga tingkat SMA/sederajat. Sementara dalam akses terhadap kesehatan, responden cenderung tetap memilih fasilitas atau tenaga kesehatan yang sama karena alasan jarak maupun biaya. Selain itu, sebagian besar responden menilai tidak terjadi perubahan meningkat dalam kondisi dan fasilitas tempat tinggal setelah hadirnya industri.

\section{Saran}

Adapun saran yang direkomendasikan bagi masyarakat yang terkena dampak industrialisasi pedesaan berdasarkan hasil penelitian yakni:

1. Masyarakat khususnya yang bekerja pada industri dapat menggunakan jaminan kesehatan berupa fasilitas kesehatan yang dirujuk oleh perusahaan demi meringankan biaya pribadi, begitu pula dengan warga non industri untuk menggunakan BPJS.

2. Lebih mengembangkan sumber daya yang dimiliki dan kreativitas agar mampu menciptakan lapangan pekerjaan baru tanpa harus bergantung pada kegiatan industri.

3. Pemerintah serta pihak perusahaan lebih memerhatikan kebijakan karena kehadiran industri mengurangi jumlah petani. Hal ini tentu 
saja perlu diperhatikan agar lahan pertanian dan jumlah petani dipastikan tetap ada untuk menjamin penyediaan pangan lokal. Masyarakat tertarik pada sektor informal (dalam hal ini menciptakan peluang berwirausaha) seiring hadirnya pabrik-pabrik di sekitar pedesaan. Peluang informal akan lebih baik lagi bila difasilitasi oleh pemerintah desa agar lebih menjamin pendapatan dan kesejahteraan masyarakat.

\section{DAFTAR PUSTAKA}

[BPS] Badan Pusat Statistik. 2015. Indikator Kesejahteraan Rakyat 2015. Jakarta (ID): Badan Pusat Statistik. [internet]. [diunduh 2017 Februari 9].Tersedia pada: http://bps.go.id/index.php/publikasi/1122

Darojah U. 2012. Perubahan struktur sosial ekonomi dari ekonomi pertanian ke ekonomi industri pada masyarakat Desa Kubangwungu Kecamatan Ketanggungan Kabupaten Brebes. Journal of Educational Social Studies [internet]. [diunduh 21 Oktober 2016]. 1(2). Tersedia pada http://journal.unnes.ac.id/sju/index.php/jess/a rticle/view/734

Gandi R. 2011. Pengaruh industrialisasi pedesaan terhadap taraf hidup masyarakat di RW 01 dan RW 09 Desa Benda, Kecamatan Cicurug, Kabupaten Sukabumi, Provinsi Jawa Barat. [skripsi]. Bogor (ID): Institut Pertanian Bogor. [internet]. [diunduh 22 Oktober 2016]. Tersedia pada: http://repository.ipb.ac.id/bitstream/12345678 9/51851/1/i11rga.pdf

Istiqomah N, Prasetyani D. 2013. Analisis dampak keberadaan kawasan industri di Desa Butuh terhadap peningkatan aktivitas perekonomian masyarakat di Kecamatan Mojosongo Kabupaten Boyolali. Jurnal JP FEB Unsoed. [internet]. [diunduh 21 Oktober 2016]. 3(1). Tersedia pada: http://jp.feb.unsoed.ac.id/index.php/sca1/article/viewFile/271/276

Purwanto. 2003. Perubahan pola pencaharian nafkah masyarakat petani di sekitar kawasan industri (Kasus di Desa Ngoro, Kabupaten Mojokerto, Jawa Timur). [tesis]. Bogor(ID): Insitut Pertanian Bogor.
Prihawantoro S, Muchdie. 2000. Industrialisasi dan pengaruhnya terhadap kesejahteraan masyarakat perdesaan. Jurnal Pengembangan Wilayah Perdesaan dan Kawasan Tertentu: Sebuah Kajian Eksploratif. [internet]. [diunduh 3 April 2017]. Tersedia pada : http://repository.uhamka.ac.id/161/1/INDU STRIALISASI $\% 20$ DAN\%20PENGARUHNYA20TERHADA P\%20KESEJAHTERAAN\%20MASYARA KAT\%20PERDESAAN.pdf

[RI] Undang-Undang Nomor 3 Tahun 2014 tentang Perindustrian. [internet]. [diunduh 10 Februari 2017]. Tersedia pada: http://www.kemenperin.go.id/download/51 81/Undang-Undang-No-3-Tahun-2014Perindustrian

Sastrosoenarto, H. 2006. Industrialisasi Serta Pembangunan Sektor Pertanian dan jasa Menuju Visi Indonesia 2030. Jakarta (ID): PT Gramedia Pustaka Utama.

Sulasmono BS. 1994. Respons masyarakat desa terhadap pembangunan industri besar (Kasus Desa Hardjosari, Kecamatan Bawen, Kabupaten Semarang, Jawa Tengah.[tesis].Bogor (ID): Institut Pertanian Bogor.

Tambunan M. 1989. Industrialisasi Pedesaan (IP) dalam Perspektif Ekonomi Nasional. Prosiding dalam Seminar Industrialisasi Pedesaan. Bogor, 18-19 Desember 198 